\title{
The Same Question: Are Migrants from the Middle East to Greece Carriers of Resistant Bacteria? In 2015, the Answer was No, but in 2019 it is Yes (Letter to editor)
}

D. Kalatova (Dagmar Kalatova)', M Luliak (Milan Luliak)², Y. Trilinskaya (Yana Trilisinskaya)², L. Janovicova (Lucia Janovicova)², T. Simonek (Tomas Simonek)², A. Liskova (Anna Liskova)², M.Hamornik (Michal Hamomik)4, M. Mrazova (Mariana Mrazova)2,5 V. Krcmery (Vladimir Krcmery)4, 5. Subramaniam (Selvaraj Subramaniam) ${ }^{6}$, M. Olah (Michal Olah)7,8, D. Barkasi (Daniela Barkasi) ${ }^{9}$, A. Beresova (Anna Beresova) ${ }^{10}$

1 Institute of Jan Nepomuk Neumann, St. Elizabeth Univ, Pribram, Original Article Czech Republic.

2 Refugee Camp UNHCRAlexandia, Refugee and Migrant Centre Lesbos, Greece.

3 Migrant Health program SEU Bratislava, Nat. ref. Lab for ATB Resistance, Nitra, Slovakia.

${ }^{4}$ Inst of Microbiology, School of Medicine Commenius University, Bratislava, Slovakia.

5 Slovak Tropical Institute, Slovak Med Univ, Bratislava, Slovakia.

${ }^{6}$ Public Health MS program SEU and SAAARMM, Kuala Lumpur, Malaysia.

7 St. Elizabeth University of Health and Social Work in Bratislava, Slovakia.

8 The PRIGO University, Havirov, Czech Republic.

9 St. Elizabeth University of Health and Social Work in Bratislava, Detached Workplace bl. Metod D. Trcka, Michalovce, Slovakia.

${ }^{10}$ St. Elizabeth University of Health and Social Work in Bratislava, Detached Workplace Z. G. Malla, Kosice, Slovakia.

\section{E-mail address:}

tropicteam@gmail.com

\section{Reprint address:}

Selvaraj Subramanian

SEUC Publ Health Joint program

Kuala Lumpur

Malaysia

Source: Clinical Social Work and Health Intervention

Pages: $60-62$

Volume: 10

Issue: 3

Cited references: 4

\section{Reviewers:}

Andrea Shahum

UNC Chapel Hill, NC, USA

Harald Stefan

Vienna General Hospital, Vienna, AT 


\section{Keywords:}

Refugee and Migrant Health. ATB Resistance. Migrant Crisis. Travel Medicine.

\section{Publisher:}

International Society of Applied Preventive Medicine i-gap

CSWHI 2019; 10(2): 60 - 62; DOI 10.22359/cswhi_10_3_06 @ 2019 Clinical Social Work and Health Intervention

\section{Abstract:}

In 2015, the surveillance cultures from respiratory tract and wounds in migrants and refugees to Greece showed only few strains of multi-resistant bacteria. In 2019, about 33-40\% of all isolates were multi-resistant to several antimicrobial agents, however the majority of refugees in $2015(90 \%)$ were from Syria and Iraq, but in 2019 the majority are from Afghanistan (40\%) and Sub-Saharan Africa (60\%). Longer travel, bad travel and housing conditions following by frequent respiratory and intestinal infections cause overuse of oral and OTC (over the counter) antibiotics resulting in resistance (MRSA ESBL but also KPC).

\section{To the Editors,}

In 2016, two papers in Clinical Social Work and Health Intervention $(1,2)$ showed that cultures obtained from migrants from Turkey to Greece and transiting in UNHCR Camps in Greece (Alexandria, Veria) showed an absence of resistant bacteria like MRSA or ESBL. Only less than $5 \%$ available ATB were resistant to the migrants $(1,2)$.

Therefore in the summer of 2019 we performed random screening of respiratory and wound isolates of those arriving at the new (2016) UNHCR camp on Lesbos Island in Greece. Results showed a very different situation in phenotypes of isolated bacteria.

While in 2015, MRSA (Methicillin resistant $S$. aureus) and ESBL-producing multi-resistant E. coli and Enterobacteriace, and Pseuromonas aeruginosa and Acinetobacter baumanii (PA and ABBA) were exceptional and represented less than $10 \%$ of isolates. Candida was the commonest isolate. In 2019, the commonest isolates were Moraxella catarrhalis (all ampicillin resistant
(MOCCA); followed by ESBL (extended spectrum betalactamase producing); Enterobacteriaceae, including two KPC producing pan-resistant $\mathrm{EC}$ and $\mathrm{ABBA}$. In addition there was a dramatic decrease of Candida spp and an increase of multi-resistant $S$. aureus and Enterobacteriaceae. This phenomenon was observed in isolates from 2019 with an increase representation of so called marine or environmental pathogens such as Stenotrophomonas maltophilia, Aeromonas hydrophila, S.gallinarum - all related to soil and water exposure during long migrations.

Trying to explain this dramatic change which may have great impact in 2020 on screening policy, again need to search for MR bacteria in addition to HIV HBV HCV and TB. We analyzed the origin of refugees and migrants and time (distance) of travel. Data on travel and nationality in 2019 in contrast to 2015 showed that while in 2015 more than 90\% were from Syria and Iraq, in 2019, majority (about 75\%) are 
Tab 1: Comparison of ATB resistant phenotypes in respiratory and wound isolates from refugee camps in Greece in 2015 (Veria, Alexandria) versus 2019 (Lesbos)

\begin{tabular}{|c|c|c|c|}
\hline Organism type & 2015(Veria,Alex) & 2019(Lesbos) & significance $\mathrm{P}$ \\
\hline No of isolates tot & 101 & 98 & ns \\
\hline MOCCA AMP-R & 12 & 21 & 0.045 \\
\hline MRSA multi R & 4 & 8 & 0.041 \\
\hline MSSA suscept & 12 & 6 & \\
\hline H.influenzae & 6 & 1 & \\
\hline S.gallinarum & 0 & 4 & \\
\hline StrPyogenes ERYR & 2 & 5 & \\
\hline Enteriobact ESBL & 1 & 2 & \\
\hline Enterobac.Sucept & 16 & 8 & \\
\hline Candida spp & 21 & 1 & 0.0002 \\
\hline Ps aeruginosa & 5 & 4 & ns \\
\hline Acinetobacter spp & 2 & 4 & ns \\
\hline Str pneumoniae & 8 & 1 & \\
\hline Streptococcus NP & 8 & 10 & \\
\hline marine org. & 0 & 4 & 0.045 \\
\hline other/negatives & 4 & 19 & \\
\hline
\end{tabular}

from Afghanistan and Sub-Saharan Africa, where the spectrum of infections is very different, and the distance and the duration of travel is significantly longer.

\section{References:}

1. P. A. HAJJ ET AL (2016) Are migrants from middle east carriers of multi-resistant bacteria. Clinical Social Work Health Interventions, 7,2016,3,10-12.

2. DUDOVA Z, TRILISINSKA Y, ET $A L$ Six months follow up of communicable diseases in Syrian an Iraqi refugee camp. Clinical Social Work Health Interventions 7.206.3.
3. CELKO J, GUTH A (2018) Occurrence of Myoskeletal Dysfunction in Professional Players musical instruments, prevention and treatment options, Rehabilitation, 2018, Vol. 55, no. 1, ISSN0375-0922, pp. 3- 16.

4. SPRINGER P, KNOSKOVA E, TULEK M, BENO P (2017) Infections diseases preventable by vaccination. In Health and Social Work. ISSN: 13336-9326. Vol. 12, No. 1. Pp. 13-24. 